\title{
Implementasi Lesson Study untuk Meningkatkan Kualitas Perkuliahan Fisika Inti
}

\author{
Haratua Tiur Maria.S, Erwina Octavianty, Hamdani \\ Pendidikan Fisika, FKIP Universitas Tanjungpura
}

\begin{abstract}
Abstrak
Lesson Study ini bertujuan untuk meningkatkan kualitas hasil dan proses perkuliahan Fisika Inti pada mahasiswa Program Studi Pendidikan Fisika Universitas Tanjungpura. Lesson Study merupakan suatu model untuk meningkatkan profesionalitas guru atau dosen dalam melaksanakan tugasnya melalui kegiatan pengkajian proses pembelajaran secara kolaboratif. Pelaksanaan Lesson Study memiliki tiga tahap yaitu : Plan (merencanakan kegiatan perkuliahan); Do (pelaksanaan perkuliahan dengan dihadiri observer); dan See (diskusi dan refleksi proses perkuliahan). Penelitian ini menerapkan perkuliahan multimodel dengan pendekatan kontekstual. Penelitian dilaksanakan dalam tiga siklus. Hasil penelitian menunjukkan bahwa proses perencanaan, pelaksanaan dan refleksi perkuliahan dapat meningkatkan kualitas hasil dan proses perkuliahan. Hasil perkuliahan mahasiswa meningkat dari rata-rata 49,25\% menjadi 78,75\%. Jadi secara umum pelaksanaan Lesson Study dapat meningkatkan kualitas perkuliahan Fisika Inti pada program studi Pendidikan Fisika.
\end{abstract}

Kata kunci : lesson study, físika inti

\section{Pendahuluan}

Salah satu masalah yang dihadapi dunia pendidikan di Indonesia pada saat ini adalah rendahnya kualitas hasil pembelajaran pada setiap jenjang pendidikan baik dari pendidikan dasar, menengah bahkan di perguruan tinggi. Hal ini terjadi terutama pada bidang studi eksakta seperti fisika dan MIPA pada umumnya.

Salah satu upaya yang dilakukan pemerintah untuk meningkatkan pendidikan adalah dengan melakukan perubahan dari kurikulum. Perubahan kurikulum dilakukan dari kurikulum yang berbasis keilmuan menjadi kurikulum yang berbasis kompetensi, dengan tujuan agar pendidikan nasional memiliki keunggulan kompetitif dan komparatif sesuai standar mutu nasional dan internasional.

Perubahan kurikulum yang terjadi menuntut adanya perubahan paradigma dari proses pembelajarannya yang berpusat pada guru menjadi pembelajaran yang berpusat pada siswa (student center). Untuk mencapai kompetensi yang telah ditetapkan tersebut, guru dituntut turut melakukan perubahan proses pembelajaran yaitu dari sekedar pembelajaran untuk tahu 
(learning to know) menjadi pembelajaran untuk berbuat (learning to do).

Program Studi Pendidikan Fisika sebagai suatu Lembaga Pendidikan Tenaga Kependidikan (LPTK) diharapkan dapat menghasilkan calon guru yang dapat mengikuti perubahan yang terjadi dalam dunia pendidikan, diantaranya perubahan paradigma pembelajaran di sekolah. Dari pengalaman terlihat bahwa seorang calon guru akan cenderung mengikuti gaya mengajar yang dialaminya ketika kuliah kelak pada saat ia menjadi pengajar. Oleh sebab itu proses perkuliahan di LPTK harus berlangsung dengan pembelajaran inovatif yang berpusat pada mahasiswa.

Salah satu mata kuliah di Program Studi Pendidikan Fisika adalah Fisika Inti di semester VI. Mata kuliah ini termasuk salah satu mata kuliah yang dianggap sulit oleh sebagian besar mahasiswa. Karakteristik materi yang abstrak membuat perkuliahan ini biasanya disampaikan dengan cara konvensional yaitu dengan metoda presentasi dan ceramah. Untuk menerapkan pembelajaran inovatif dalam perkuliahan ini, maka diimplementasikanlah Lesson Study dalam perkuliahan Fisika Inti.

Implementasi Lesson Study di

Program Studi Pendidikan Fisika dilaksanakan dengan melakukan kolaborasi antara dosen model dan dosen Program Studi Pendidikan Fisika lainnya. Inovasi pembelajaran dilakukan dengan menerapkan pendekatan kontekstual dan modelmodel pembelajaran yang dapat mengaktifkan siswa. Diharapkan hal ini akan dapat meningkatkan kualitas baik hasil maupun proses perkuliahan.

Lesson study merupakan suatu model pembinaan profesi dosen atau guru melalui kegiatan pengkajian pembelajaran secara kolaboratif. Menurut Sriyati (2005), Lesson study merupakan pembelajaran secara nyata (riil) di dalam kelas dengan siswa yang diamati guru-guru lain sebagai observer dan dilakukan kegiatan refleksi setelah proses pembelajaran selesai. Jadi kegiatan lesson study merupakan salah satu usaha untuk mengatasi masalah pembelajaran yang dihadapi dosen dan guru dalam pembelajaran, baik dalam merancang juga dalam melaksanakan proses pembelajaran.

Menurut Cerbin \& Kopp (2005), Lesson Study memiliki empat tujuan utama, yaitu untuk memperoleh pemahaman yang lebih baik tentang bagaimana siswa belajar dan guru mengajar, memperoleh hasil-hasil tertentu yang dapat dimanfaatkan oleh para guru lainnya di luar peserta Lesson Study, meningkatkan pembelajaran secara sistematis melalui inkuiri kolaboratif, dan membangun pengetahuan pedagogis dimana seorang guru dapat menimba pengetahuan dari guru lainnya.

Dalam pelaksanaannya, lesson study meliputi tiga tahapan kegiatan, yaitu perencanaan (plan), implementasi (do) dan refleksi (see). Dalam implementasinya, para dosen yang tergabung dalam lesson study berkolaborasi untuk mengidentifikasi masalah pembelajaran yang dihadapi sampai mendiskusikan alternatif kegiatan untuk mengatasi masalah tersebut. Kemudian secara kolaborasi tim melaksanakan rencana dan 
kemudian melakukan refleksi perkuliahan yang dilaksanakan.

Kegiatan lesson study ini bertujuan untuk meningkatkan kualitas hasil dan proses perkuliahan pada program studi Pendidikan Fisika. Penelitian ini diimplementasikan pada perkuliahan Fisika Inti.

\section{Metode Penelitian}

Pengembangan pembelajaran pada mata kuliah Fisika Inti pada pokok bahasan Sifat dan struktur Inti atom ini dilaksanakan melalui kegiatan Lesson Study di FKIP Untan. Kegiatan ini diikuti oleh dosen-dosen jurusan P.MIPA yang terdiri dari prodi pendidikan Fisika (sebagai pelaksana) dan prodi pendidikan Kimia, pendidikan biologi dan pendidikan matematika (sebagai observer). Proses kegiatan dilakukan dengan 3 tahap yaitu; tahan perencanaan, tahap implementasi, dan tahap refleksi.

Instrumen yang digunakan adalah Lembar Penilaian Angket Respon Mahasiswa terhadap pembelajaran, tes penguasaan konsep serta lembar observasi. Mahasiswa yang menjadi subjek penelitian adalah mahasiswa semester VI tahun ajaran 2008-2009 yang mengambil mata kuliah Fisika Inti dan berjumlah 71 mahasiswa .

Penelitian ini dilakukan dengan mengikuti tahapan atau prosedur sebagai berikut:

Tahap Plan : Membuat lesson plan (Mendisain pembelajaran/ perkuliahan agar lebih baik)

Tahap Do : Seorang dosen model mengajar; Guru/dosen lain mengamati
Tahap See :
bersama-sama
Guru/dosen
pembelajaran.

\section{Hasil dan Pembahasan}

Implementasi lesson study dalam penelitian ini dilakukan dalam 3 (tiga) siklus. Siklus ke-1 pada materi energi ikat inti, siklus ke-2 pada materi peluruhan radio aktif dan siklus ke-3 membahas konsep tentang reaksi inti. Masing-masing siklus dilaksanakan dengan kegiatan perencanaan, pelaksanaan dan refleksi. Berikut ini akan diuraikan tindakan dan pembahasan hasil penelitian pada masing-masing siklus.

Pada siklus I tahap perencanaan dilaksanakan dalam 2 kali pertemuan. Pada tahap perencanaan pertama para dosen Fisika melakukan refleksi awal tentang proses perkuliahan dan mengidentifikasi masalah perkuliahan yang terjadi untuk menentukan mata kuliah yang akan mengimplementasikan lesson study. Dari diskusi yang dilakukan teridentifikasi beberapa masalah yang terjadi dalam proses perkuliahan, diantaranya ada mata kuliah yang dianggap sulit oleh mahasiswa, hal ini tercermin dari tingkat kelulusan dan nilai yang dicapai oleh mahasiswa.

Fisika Inti merupakan salah satu mata kuliah wajib bagi mahasiswa program studi Pendidikan Fisika yang dianggap sulit oleh sebagian besar mahasiswa. Materi yang abstrak dan proses perkuliahan yang cenderung bersifat informatif membuat mata kuliah ini menjadi tidak menarik bagi mahasiswa. Hal ini juga diperoleh dari hasil 
wawancara dengan beberapa mahasiswa yang sudah mengikuti perkuliahan ini.

Dari hasil diskusi tim bersama dengan beberapa guru Fisika yang berasal dari sekolah (SMP dan SMA) terungkap bahwa konsep ini sangat penting dikuasai mahasiswa sebagai calon guru, mengingat konsep ini juga ditemukan dalam pelajaran Fisika khususnya di SMA. dengan Padahal mata kuliah ini adalah mata kuliah yang essensial. Setelah menentukan materi, kemudian ditentukan dosen model yang akan mengimplementasikan rencana yang disusun.

Dari permasalahan yang ditemukan diatas, kemudian para dosen Fisika melakukan diskusi untuk mencari solusi pembelajaran yang lebih baik yang akan diterapkan pada pelaksanaan pembelajaran siklus pertama. Melalui diskusi yang dilakukan disepakati untuk siklus pertama digunakan penerapan pembelajaran Fisika Inti dengan pendekatan kontekstual.

adalah multimodel yang dipilih menggabungkan model generatif dan model kooperatif teknik Think-PairShare. Pemilihan model generatif dimaksudkan untuk membantu mahasiswa dalam membangun pengetahuannya sendiri secara aktif tentang energi ikat inti. Pemilihan model ini juga dimaksudkan untuk meningkatkan minat siswa dalam belajar Fisika inti dengan cara mengkaitkan dengan penerapannya dalam kehidupan sehari-hari. Model kooperatif dimaksudkan untuk memberikan kesempatan kepada siswa belajar secara kelompok.
Pelaksanaan pembelajaran dilaksanakan pada hari Jum'at tanggal 20 Maret 2009. Pada tahap ini dilakukan pembelajaran sesuai dengan perangkat pembelajaran yang telah dibuat pada tahap perencanaan. Sebelum pelaksanaan perkuliahan, dosen model diberi kesempatan menyampaikan secara ringkas rencana yang akan dilakukannya pada suatu pertemuan singkat. Hal ini dimaksudkan agar observer dapat merencanakan pengamatan yang akan dilakukan. Pada pertemuan singkat ini juga disampaikan instrumen pedoman observasi pembelajaran yang dapat dijadikan penekanan aspek pengamatan yang akan dilakukan.

Pada awal pembelajaran dosen berusaha memotivasi mahasiswa dengan menunjukkan animasi fenomena ledakan akibat bom atom yang disebabkan peristiwa pemisahan energi. Kemudian dosen menggali pengetahuan awal mahasiswa dengan menanyakan penyebab ledakan bom, kemudian berusaha menimbulkan adu argumentasi oleh mahasiswa.

Langkah berikutnya dosen menyampaikan aturan perkuliahan tentang model pembelajaran yang diimplementasikan yaitu Think-PairShare. Mahasiswa dibagikan handout kemudian diminta membaca dan merenungkannya (Think) sebelum mendiskusikan dengan teman disampingnya (Pair). Dosen kemudian meminta beberapa mahasiswa menyajikan pendapatnya, kemudian didiskusikan secara klasikal (Share). Kegiatan berikutnya adalah mahasiswa diberi contoh soal dan kemudian diberi beberapa soal sebagai latihan untuk menerapkan 
pengetahuannya dalam menyelesaikan soal tentang energi ikat inti.

$$
\text { Pada bagian akhir }
$$
pembelajaran, mahasiswa diarahkan membuat rangkuman tentang materi yang dipelajari. Penghargaan diberikan pada kelompok yang berperan paling aktif dalam proses pembelajaran. Sebagai penutup dosen melakukan refleksi pembelajaran yang telah berlangsung dan memberikan tugas untuk dikerjakan mahasiswa.

Dari hasil tindakan (Do) siklus I dan pengamatan para observer, diperoleh gambaran secara umum bahwa dosen model telah berupaya melaksanakan perkuliahan dengan baik yang dapat meningkatkan aktivitas mahasiswa dalam proses perkuliahan. Fokus observasi diarahkan pada proses perkuliahan mahasiswa.

Beberapa hal yang menjadi fokus pengamatan adalah : interaksi antara mahasiswa dengan mahasiswa, interaksi antara mahasiswa dengan dosen, eksplorasi yang dilakukan mahasiswa dan dosen, serta manfaat yang diperoleh oleh dosen model dan observer.

$$
\text { Kegiatan lesson study }
$$

bermanfaat memotivasi dosen model dan observer untuk merencanakan perkuliahan dengan kreatif sehingga perkuliahan menjadi menarik, khususnya pada materi-materi abstrak. Media pembelajaran menggunakan animasi-animasi menarik sehingga mahasiswa tertarik. Selain itu media pembelajaran sudah cocok dengan bahan ajar dan mendukung perkuliahan, sehingga dapat di adopsi dan dimodifikasi. Secara umum observer berpendapat bahwa kegiatan lesson study dapat meningkatkan kualitas proses pembelajaran.

Berdasarkan pada refleksi yang telah dilakukan maka terdapat rekomendasi untuk perbaikan pada siklus selanjutnya.

1. Meningkatkan kinerja dosen yang dirasa masih kurang baik, namun mempertahankan kinerja yang sudah baik.

2. Kelompok diskusi dibuat dengan anggota kelompok yang merata, sehingga kegiatan berdiskusi kelompok dapat berjalan lancar. Dan anggota kelompok sebaiknya hanya $6-8$ orang dalam satu kelompok, serta pengorganisasian kelompok dengan jelas.

Kegiatan plan pada siklus
kedua dimulai dengan
mendiskusikan rencana pembelajaran
dan perangkat yang telah disusun
oleh dosen model. Pada awalnya
dosen model merencanakan akan
menggunakan pembelajaran
multimodel seperti pada siklus ke-1. Namun berdasarkan diskusi keterbatasan yang telah ditemukan pada pelaksanaan siklus pertama, maka dalam pelaksanaan siklus kedua model diubah menjadi pembelajaran kooperatif teknik jigsaw dan NHT (numbered head together) dalam pembelajaran tentang materi peluruhan radio aktif. Model kooperatif NHT dipilih sebagai hasil refleksi dari siklus sebelumnya bahwa masih ada sebagian mahasiswa yang belum terlibat aktif dalam proses 
perkuliahan. Dengan penomoran dan kemudian cara undian untuk menentukan mahasiswa yang diminta mewakili kelompok, diharapkan semua mahasiswa termotivasi untuk lebih aktif dan sungguh-sungguh dalam kegiatan. Tipe Jigsaw di pilih untuk membantu efisiensi waktu kegiatan, karena adanya beberapa prinsip paralel dalam materi peluruhan radio aktif, yaitu peluruhan $\alpha, \beta$ dan $\gamma$.

Perbaikan pada perangkat dilakukan dalam menyusun rencana langkah kegiatan. Selain pada skenario perkuliahan, perbaikan juga dilakukan dalam hand-out perkuliahan dan animasi yang digunakan dalam perkuliahan. Diskusi juga merancang pembagian kelompok dalam pembelajaran, dimana jumlah anggota kelompok pada siklus ke-2 lebih sedikit dari kelompok pada siklus ke-1. Selain pembagian kelompok, diskusi juga menghasilkan denah tempat duduk bagi mahasiswa peserta lesson study.

Pelaksanaan pembelajaran dilaksanakan pada hari Senin tanggal 13 April 2009. Pada tahap ini dilakukan pembelajaran sesuai dengan perangkat pembelajaran yang telah dibuat pada tahap perencanaan.

Pada awal pembelajaran dosen berusaha memotivasi mahasiswa dengan menyajikan salah satu pemanfaatan sinar radio aktif dalam bentuk karikatur. Kemudian dosen menggali pengetahuan awal mahasiswa dengan menanyakan konsepsi siswa tentang peluruhan radioaktif.
Pada kegiatan berikutnya, dosen menyampaikan aturan langkah-langkah perkuliahan dalam pembelajaran kooperatif tipe Jigsaw dan NHT. Dosen membagi mahasiswa yang telah duduk dalam formasi kelompok asal kedalam kelompok ahli $\alpha, \beta$ dan $\gamma$.

Terdapat 3 kelompok $\alpha, 3$ kelompok $\beta$ dan 2 kelompok $\gamma$. Kemudian mahasiswa berdiskusi dalam kelompok masing-masing dengan bimbingan dosen. Selanjutnya dosen meminta salah satu mahasiswa dari kelompok ahli untuk mempresentasikan peluruhan radioaktif $\alpha, \beta$ dan $\gamma$. Untuk evaluasi, dosen menerapkan NHT yaitu dengan cara meminta mahasiswa mengerjakan LKM 2 dalam kelompok asalnya, dan kemudian memanggil beberapa orang secara acak berdasarkan nomor dari masing-masing kelompok.

Pada bagian akhir perkuliahan, dosen membimbing mahasiswa menyimpulkan materi perkuliahan dan memberikan penghargaan kepada kelompok yang terbaik. Evaluasi individu diberikan berupa soal pilihan ganda yang dikerjakan masing-masing mahasiswa.

Dari hasil tindakan (Do) siklus II dan pengamatan para observer, diperoleh gambaran secara umum bahwa dosen model telah berupaya melaksanakan perkuliahan dengan baik yang dapat meningkatkan aktivitas mahasiswa dalam proses perkuliahan. Fokus observasi diarahkan pada proses perkuliahan mahasiswa dengan fokus pengamatan tetap 4 aspek yang meliputi interaksi dan eksplorasi 
mahasiswa dengan dosen serta manfaat kegiatan.

Dari hasil refleksi terlihat bahwa diskusi mahasiswa berjalan lebih baik dari pada kegiatan open lesson yang pertama. Namun masih terdapat juga beberapa siswa yang kurang aktif. Karena kelompok telah ditentukan terlebih dahulu, pengorganisasian tugas dan kelompok menjadi tidak merata jumlahnya karena faktor hujan yang membuat sebagian mahasiswa tidak hadir.

Proses eksplorasi pemahaman materi ajar oleh mahasiswa berlangsung baik dan cukup aktif, melalui diskusi soal, telaah hand-out dan penguatan materi oleh dosen.

Kegiatan Lesson study ini membawa dampak dalam pengembangan proses pembelajaran. Dimana beberapa obsever berpendapat bahwa dengan kegiatan open lesson ini, dapat mengetahui celah - celah masalah dalam diskusi kelompok dan cara untuk mengantisipasinya, serta cara melakukan proses eksplorasi pemahaman materi ajar secara mandiri.

Berdasarkan pada refleksi yang telah dilakukan maka terdapat rekomendasi untuk perbaikan pada siklus selanjutnya.

1. Meningkatkan kinerja dosen yang dirasa masih kurang baik, namun mempertahankan kinerja yang sudah baik.

2. Perlu mempertimbangkan beberapa hal termasuk cuaca dalam menentukan kelompok.

3. Interaksi di dalam kelompok dan antar kelompok perlu diberikan porsi yang lebih besar untuk berinteraksi dan diberikan motivasi sehingga ada kesempatan bagi mahasiswa pasif untuk bertanya dan mengeluarkan ide dan gagasan. Selain itu terjadi peningkatan interaksi antara dosen dan mahasiswa.

Kegiatan plan pada siklus
ketiga dimulai
mendiskusikan rencana pembelajaran dan perangkat yang telah disusun oleh dosen model. Pada awalnya dosen model merencanakan akan menggunakan pembelajaran kooperatif teknik jigsaw dan NHT (numbered head together) seperti pada siklus ke-2. Namun berdasarkan diskusi oleh tim dosen Fisika, maka dalam pelaksanaan siklus ketiga model diubah menjadi pembelajaran multimodel yang menggabungkan model generatif dan kooperatif dalam pembelajaran tentang materi reaksi inti. Model generatif dipilih dengan harapan langkah-langkah dalam model generatif dapat membantu mahasiswa untuk membangun sendiri konsepsinya tentang reaksi inti. Sedangkan pembelajaran kooperatif dimaksudkan, selain untuk memberi kesempatan mahasiswa belajar berdiskusi dan bekerja bersama temannya, juga memberi kesempatan pada dosen model lebih mengoptimalkan bimbingannya untuk meningkatkan kompetensi sosial mahasiswa. 
Pelaksanaan pembelajaran dilaksanakan pada hari Jum'at tanggal 1 Mei 2009. Pada awal pembelajaran dosen berusaha memotivasi mahasiswa dengan memberikan suatu pantun yang dimaksudkan sebagai salam pembuka perkuliahan. Kegiatan ini spontan dilakukan dosen model dan tidak termuat dalam rencana perkuliahan. Kemudian dosen menampilkan animasi ledakan bom seperti pada pertemuan ke-1, dan meminta pendapat mahasiswa tentang fenomena tersebut dan kemudian mengarahkan untuk memunculkan judul perkuliahan tentang reaksi inti. Selanjutnya dosen menggali pengetahuan awal mahasiswa dengan memunculkan gambar reaktor atom dan matahari, lalu menanyakan perbedaan antara keduanya.

$\begin{array}{ll}\text { Pada kegiatan berikutnya } & \text { dosen meminta mahasiswa }\end{array}$
mendiskusikan hand out dan LKM 1 pada kelompoknya masing-masing. Kemudian dosen meminta perwakilan kelompok untuk mempresentasikan hasil diskusinya untuk menemukan konsep reaksi inti, reaksi fisi dan reaksi fusi. Mahasiswa juga diberi kesempatan berlatih menyelesaikan soal-soal perhitungan tentang energi yang dilepas pada reaksi inti. Hasil perhitungan ini kemudian didiskusikan untuk menemukan penyebab tentang daya rusak suatu bom atom. Pada bagian akhir perkuliahan, dosen membimbing mahasiswa menyimpulkan materi perkuliahan dan memberikan penghargaan kepada kelompok yang terbaik. Aplikasi dalam hidup sehari-hari disampaikan tentang bahaya dari reaksi inti dalam kehidupan. Evaluasi individu diberikan berupa soal pilihan ganda yang dikerjakan masing-masing mahasiswa.

Dari hasil tindakan (Do) siklus III dan pengamatan para observer, diperoleh gambaran secara umum bahwa dosen model telah berupaya melaksanakan perkuliahan dengan baik yang dapat meningkatkan aktivitas mahasiswa dalam proses perkuliahan. Fokus observasi tetap diarahkan pada proses perkuliahan mahasiswa dan ditambah dengan langkah perkuliahan. Hal ini dilakukan untuk meningkatkan proses perkuliahan yang dilakukan oleh dosen model.

Salah satu hal yang menjadi fokus pengamatan adalah lengkah perkuliahan. Kegiatan awal yang dilakukan oleh dosen model sudah sesuai dengan SAP yang telah disiapkan, namun dalam menggali informasi dan pemahaman awal mahasiswa masih kurang dalam.

Pada kegiatan inti kesesuaian SAP telah dipertahankan oleh dosen model, namun dalam pengerjaan LKM tidak diberikan instruksi jelas oleh dosen mengenai waktu, cara menjawab soal atau bahan ajar yang bisa digunakan oleh mahasiswa. Dampaknya ketika masuk pada kegiatan inti, mahasiswa masih terlihat bingung dengan hal - hal yang harus mereka lakukan.

Pada kegiatan akhir dilakukan penegasan kembali kesimpulan keseluruhan perkuliahan. Dosen menyampaikan pemanfaatan dan bahaya tapi tidak ada fase review 
materi perkuliahan dan penghargaan pada kelompok terbaik.

Interaksi antara mahasiswa dengan mahasiswa melalui diskusi berjalan lebih baik dari pada kegiatan open lesson sebelumnya. Namun masih ada mahasiswa yang terfokus pada mengerjakan soal dibandingkan dengan diskusi membahas soal secara berkelompok.

Secara keseluruhan diskusi antar mahasiswa dan antar kelompok berjalan dengan baik. Kemampuan mahasiswa dalam mengajukan pertanyaan, ide dan gagasan serta menjawab beberapa pertanyaan sudah nampak tidak canggung antar mahasiswa, bahkan terjadi debat antar mahasiswa tentang pembangunan PLTN menerapkan reaksi fusi atau reaksi fisi.

Interaksi antara mahasiswa dan dosen sudah intensif, dosen aktif baik dalam memfasilitasi kegiatan diskusi dalam kelompok dan antar kelompok. Namun pembagian perhatian dan pemberian bimbingan dosen masih belum dilakukan secara optimal. Interaksi yang terjadi sudah dua arah dengan frekuensi yang sering terjadi komunikasi. Dosen memberikan kesempatan mahasiswa dengan porsi yang lebih besar untuk mengeluarkan ide dan gagasan serta menjawab pertanyaan dosen. Mahasiswa tampak antusias dalam kegiatan kelompok dan presentasi kelompok.

Eksplorasi yang dilakukan mahasiswa dan dosen sudah cukup baik. Proses eksplorasi pemahaman materi ajar yang dilakukan oleh dosen sangat membantu mahasiswa dalam memahami materi yang didiskusikan, penjelasan materi dimulai dari konsep yang sederhana sampai konsep aplikasi. Pada presentasi mahasiswa turut aktif menjelaskan hasil diskusi yang diperolehnya dalam kelompok. Proses eksplorasi pemahaman materi ajar oleh mahasiswa berlangsung baik dan cukup aktif, melalui diskusi soal, telaah hand-out dan penguatan materi oleh dosen.

Manfaat kegiatan lesson study dalam meningkatkan kualitas proses perkuliahan terlihat karena dosen model dan observer termotivasi dalam melakukan perencanaan dan implementasi proses perkuliahan yang sudah direncanakan dan mempraktekkan dalam perkuliahan yang direncanakan tersebut secara kreatif, inovatif.

Analisis terhadap hasil tes individu mahasiswa menunjukkan bahwa terjadi peningkatan pemahaman konsep mahasiswa dari rata-rata $49,25 \%$ pada tes awal menjadi 78,75 \%. Hal ini menunjukkan bahwa terjadi peningkatan kualitas hasil perkuliahan.

Beberapa obsever berpendapat bahwa dengan kegiatan open lesson ini, dapat dijadikan bahan referensi cara pengelolaan perkuliahan sehingga memberikan perkuliahan yang berkualitas dan menyenangkan.

\section{Simpulan dan Saran}

Berdasarkan pembahasan dan refleksi yang telah diuraikan, dapat disimpulkan hal-hal sebagai berikut. 
1. Implementasi lesson study dapat meningkatkan kualitas hasil perkuliahan.

2. Implementasi lesson study dapat meningkatkan kualitas proses perkuliahan

3. Kegiatan lesson study pada mata kuliah Fisika Inti dapat meningkatkan motivasi belajar mahasiswa

Saran-saran yang dapat direkomendasikan dari penelitian ini adalah:

1. Situasi dan kondisi kelas seperti pembagian kelompok dan denah tempat duduk perlu di informasikan kepada mahasiswa

sebelum pelaksanaan perkuliahan.

2. Mencermati manfaat yang diperoleh dosen-dosen observer melalui kegiatan lesson study. Disarankan kepada dosen-dosen untuk sesering mungkin melihat pembelajaran yang dilakukan oleh dosen lain, dan memotivasi siswa untuk mengasah keterampilan proses sains.

\section{Daftar Pustaka}

Bill Cerbin \& Bryan Kopp. (2005). A Brief Introduction to College Lesson Study. Lesson Study Project. online: http://www.uwlax.edu/sot1/lsp/i ndex $2 . h t m$
Catherine Lewis (2002) Does Lesson Study Have a Future in the United States? Online: http://www.sowionline.de/journal/20041/lesson_lewis.htm

Hendayana, dkk. 2006. Lesson Studi: Suatu Strategi untuk Meningkatkan Keprofesionalan Pendidik. Bandung: UPI PRESS.

Hendayana, S dkk. (2007). Lesson Study Suatu Strategi Untuk Meningkatkan Keprofesionalan Pendidik (Pengalaman ImstepJica). Bandung : FPMIPA UPI dan JICA.

Rustaman, N dkk.(2005). Strategi Belajar Mengajar Biologi. Malang: Universitas Negeri Malang.

Slamet Mulyana. 2007. Lesson Study (Makalah). Kuningan: LPMPJawa Barat

Sriyati, S. (2005). Reformasi Sekolah melalui Lesson Study. Makalah pada seminar Nasional Pendidikan IPA II dengan tema Membangun Pendidikan IPA Masa Depan yang Kompetitif. 22-23 Juli 2005 di FPMIPA UPI Bandung 